WellBeing International

WBI Studies Repository

2013

\title{
Identification of the Rainbowfish in Lake Eacham Using DNA Sequencing
}

Culum Brown

Macquarie University

Yagiz Aksoy

Macquarie University

Hilal Varinli

Macquarie University

Michael Gillings

Macquarie University

Follow this and additional works at: https://www.wellbeingintlstudiesrepository.org/acwp_vsm

Part of the Animal Studies Commons, Biodiversity Commons, and the Terrestrial and Aquatic Ecology Commons

\section{Recommended Citation}

Brown, C., Aksoy, Y., Varinli, H., \& Gillings, M. (2013). Identification of the rainbowfish in Lake Eacham using DNA sequencing. Australian Journal of Zoology, 60(5), 334-339.

This material is brought to you for free and open access by WellBeing International. It has been accepted for inclusion by an authorized administrator of the WBI Studies Repository. For more information, please contact wbisr-info@wellbeingintl.org.

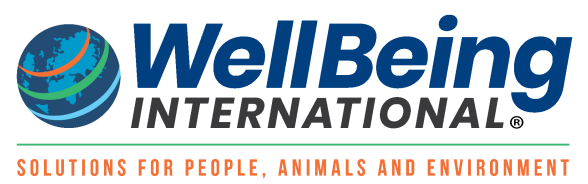




\title{
Identification of the Rainbowfish in Lake Eacham Using DNA Sequencing
}

\author{
Culum Brown, Yagiz Aksoy, Hilal Varinli, and Michael Gillings
}

Macquarie University

\author{
KEYWORDS \\ colonisation, Melanoteania, translocation
}

\begin{abstract}
The Lake Eacham rainbowfish (Melanotaenia eachamensis) was once thought to be confined to its type locality within the Lake Eacham World Heritage National Park. M. eachamensis disappeared from the lake following the translocation of several species into the lake and the species was pronounced extinct in the wild in 1987. In a 2007 survey we noticed that rainbowfish were present in the lake once again. We used a molecular marker to identify these fish and the likely source population. Analysis of the $D$ loop region of mitochondrial DNA revealed that the species now present in the lake is Melanotaenia splendida, and is most closely related to several M. splendida populations in the immediate vicinity. Here we explore a range of scenarios that may have led to this colonisation event and highlight the dangers associated with translocation.
\end{abstract}

\section{Introduction}

The tale of the Lake Eacham rainbowfish (Melanotaenia eachamensis Allen \& Cross) is something of an Australian conservation biology saga. This species was once thought to be confined to its type locality, Lake Eacham, an isolated crater lake on the Atherton Tablelands in the hinterlands of Cairns. Prior to the 1980s the species was highly abundant and commonly observed along the fringe of the lake shore (Allen and Cross 1982). The lake itself has a raised surround and the catchment has been entirely isolated from the neighbouring Barron, Mulgrave and North Johnstone River systems for at least 6000 years (Timms 1979). The only other fish species present in the lake at the time of the survey were the fly-specked hardyhead (Craterocephalus stercusmuscarum Gunther) and the northern trout gudgeon (Mogurnda mogurnda Richardson) (Allen and Cross 1982).

Sometime between 1983 and 1987 several other species were translocated into the lake, including mouth almighty (Glossamia aprion), banded grunter (Amniataba percoides), bony bream (Nematalosa erebi) and the archer fish (Toxotes chatareus), all of which are abundant in the surrounding streams (Barlow et al. 1987). Shortly thereafter the Lake Eacham rainbowfish vanished entirely; the first reported extinction of a vertebrate from within a World Heritage National Park in Australian history (Wager 1993). It was also the first freshwater fish to be pronounced extinct in Australia. The northern trout gudgeon and yabby (Cherax cairnsensis) were also reportedly missing from the survey (Barlow et al. 1987). The most popular 
explanation for the disappearance was that the rainbowfish was predator naïve because of its long history in isolation and thus succumbed to predation principally by the mouth almighty. Later comparative examinations of the species' antipredator behaviour supported this notion (Brown and Warburton 1997).

Following its disappearance from the lake, M. eachamensis was listed as extinct in the wild. Fortunately, aquarium enthusiasts had unofficially collected the fish and established breeding colonies in captivity (Barlow et al. 1987). These populations were later to become the centre of attempts to reintroduce the fish to the lake in 1989 and the early 1990s, all of which failed in spectacular fashion despite the fact that the captive populations retained a significant level of genetic variation (Zhu et al. 1994). In a single restocking event, 3000 fish were released into the lake and none were resighted just three months later. Several studies have since shown that rainbowfish populations vary dramatically in their predator recognition and antipredator behaviour (Brown and Warburton 1997, 1999; Brown 2003) and that captivereared populations show a loss of shoaling behaviour (Kydd and Brown 2009) and atypical stress responses (Zuberi et al. 2011). No attempt was made to train the fish to recognise and respond to predators before reintroduction, or to remove the translocated species, which is now recognised as best practice (Brown and Laland 2001; Brown and Day 2002).

Following these failures there was some reluctance to continue supporting the attempts to manage the species and questions were raised about its distinctiveness from the surrounding populations of $M$. splendida (Wager 1993). Crowley and Ivantsoff (1991), for example, found that the morphometrics of $M$. eachamensis overlapped with $M$. splendida in every criterion and they found no differences at allozyme loci. Zhu et al. (1994), however, showed significant divergence between the two species in the nucleotide sequences of segments of the cytochrome $b$ gene and the tRNA (Pro) control region. This new information led to a rapid reevaluation of the species as a discrete evolutionarily significant unit worthy of further protection (Zhu et al. 1998).

Allen (1989) reported a population of fish that seemed to closely resemble $M$. eachamensis in the nearby Dirran Creek, a tributary of the North Johnstone River. Follow up surveys and analysis based on morphometrics and meristics identified that $M$. eachamensis was alive and well in the wild (Pusey et al. 1997), but at least some of these samples were incorrectly identified, probably owing to the high degree of phenotypic plasticity in rainbowfish (McGuigan et al. 2003) and the fact that most meristic characters show a high degree of overlap within the family (Allen and Cross 1982; Crowley and Ivantsoff 1991). Further analysis using molecular tools showed that the species was isolated to just a few small populations, including those at Dirran Creek and Lake Euramoo (Zhu et al. 1998; McGuigan et al. 2000). Analysis using mtDNA, nuclear microsatellites, and morphometric characters showed that $M$. eachamensis populations were entirely distinct from the surrounding $M$. splendida populations and were more closely aligned with $M$. australis (Zhu et al. 1998; McGuigan et al. 2000). Despite its re-emergence from the ashes, $M$. eachamensis is still listed as critically endangered by the IUCN and little is known about its current distribution and abundance.

Sometime between 2000 and 2007, rainbowfish reappeared in Lake Eacham (Fig. 1a). The visual appearance of these fish resembled $M$. splendida, which is common in many of the surrounding waterways. The purpose of the present paper was to confidently identify the fish and determine the likely source population using molecular tools. Molecular techniques are particularly useful in the present context because the traditional morphometric and meristic analyses are too unreliable for identification of rainbowfish species (Crowley and Ivantsoff 1991; Zhu et al. 1998; McGuigan et al. 2000). Moreover, molecular analysis has repeatedly revealed cryptic species diversity in the Australian freshwater fauna (e.g. Page et al. 2004; Faulks et al. 2010) and is rapidly becoming a vital tool for identifying and conserving biodiversity. 
Fig. 1. (a) A male rainbowfish specimen captured in Lake Eacham in 2007 and identified as $M$. splendida using mtDNA sequencing. (b) A male M. eachamensis from Dirran Creek.
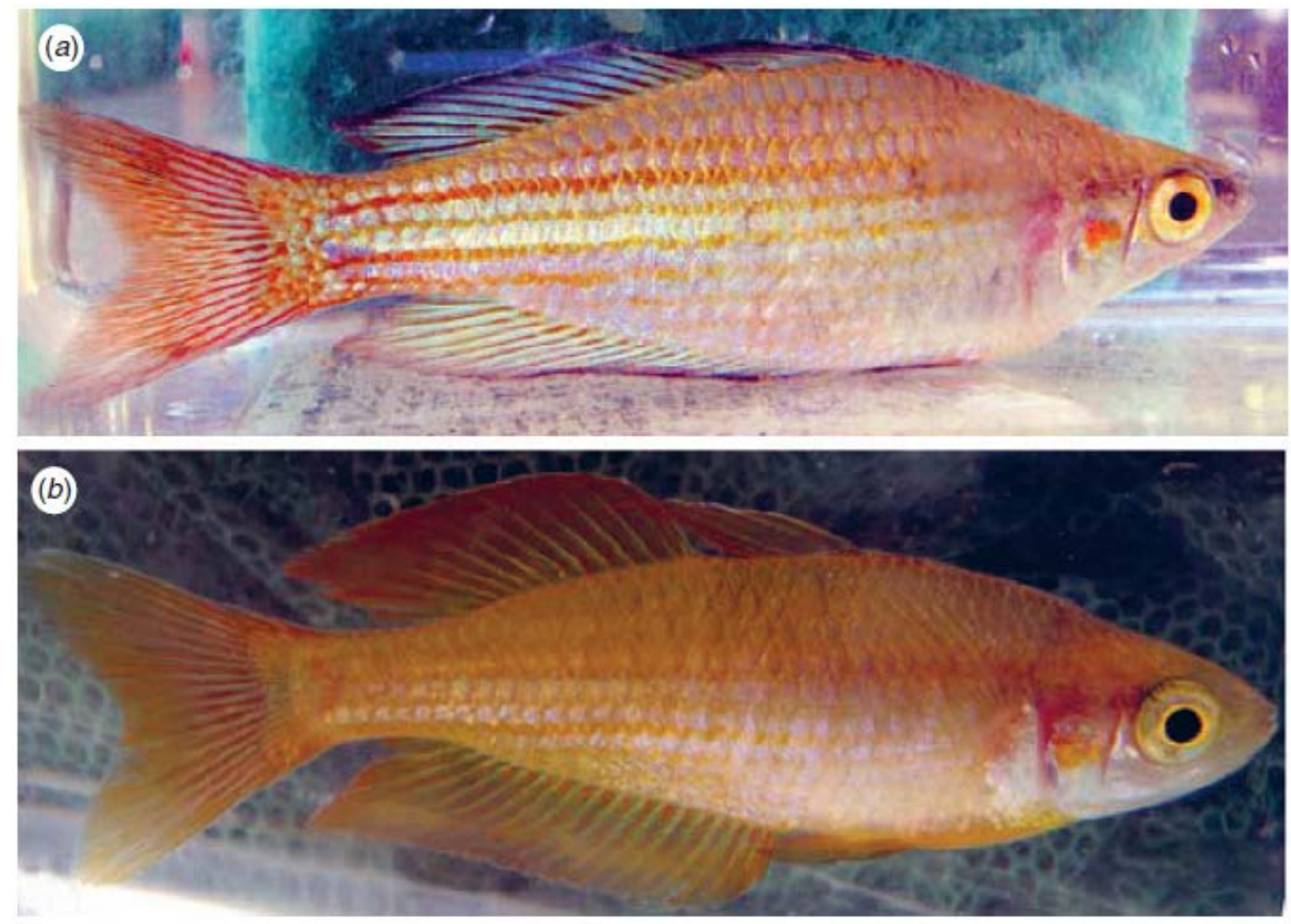

\section{Methods}

Between 2007 and 2011 we collected fish from the surrounding areas at various distances from Lake Eacham. Because we suspected the fish in the lake was $M$. splendida rather than $M$. eachamensis, most of the samples were taken from populations known to contain the former (Table 1). As a reference we included a sample from the captive-reared population of $M$. eachamensis that once inhabited Lake Eacham as well as the best known wild population of $M$. eachamensis from Dirran Creek (Fig. $1 b$ ). We sampled various locations including a single lowland population of $M$. splendida from the Tully River system, which is less likely to be the source population given both its geographical location in a disjunct drainage and the great linear distance to Lake Eacham. Davies Creek is also a significant distance and geographically isolated from Lake Eacham but it is part of the Barron River catchment which drains from Lake Tinaroo, offering another geographically distant population. This population has attracted the attention of aquarium enthusiasts because of its unusual appearance. Wright Creek is north of Lake Eacham and runs into Lake Tinaroo. Lake Barine is an isolated crater-lake catchment but overflows into Toohey Creek during very wet seasons and ultimately into the Mulgrave River. Gadgarra Creek is a small tributary of Toohey Creek. The remaining populations are part of the North Johnstone River catchment (see Fig. 2). 
Table 1. Locations of fish populations sampled and the distance from Lake Eacham. Note that distances are linear and do not represent in-stream distances, which are substantially greater.

\begin{tabular}{|llclccc|}
\hline Species & Location & Key & Catchment & Latitude & Longitude & Distance (km) \\
\hline M. eachamensis & Captive & & & 17.008926 & 145.583499 & n.a. \\
M. eachamensis & Dirran Creek & & North Johnstone & 17.470336 & 145.553167 & 22.5 \\
M. splendida & Lake Eacham & LE & Lake Eacham & 17.285142 & 145.629010 & 0 \\
M. splendida & Wright Creek & WR & Barron & 17.280111 & 145.632099 & 0.5 \\
M. splendida & Malanda Creek & M & North Johnstone & 17.299520 & 145.634724 & 2.5 \\
M. splendida & Lake Tinaroo & TIN & Barron & 17.171739 & 145.551381 & 3 \\
M. splendida & Gadgarra Creek & GC & Mulgrave & 17.273081 & 145.666196 & 4 \\
M. splendida & Johnstone River & JR & North Johnstone & 17.363136 & 145.642399 & 9.5 \\
M. splendida & Theresa Creek & TC & North Johnstone & 17.475396 & 145.655945 & 22 \\
M. splendida & Davies Creek & DAV & Barron & 17.008926 & 145.583499 & 31.5 \\
M. splendida & Jarra Creek & JA & Tully & 17.897901 & 145.850853 & 72.5 \\
\hline
\end{tabular}

Fig. 2. Location of the sample sites in the Atherton Tablelands. The lower left-hand box shows an enlargement of the area around Lake Eacham, showing the sites and the linear distances to Lake Eacham. $S$ = M. splendida, $\mathrm{E}=M$. eachamensis.

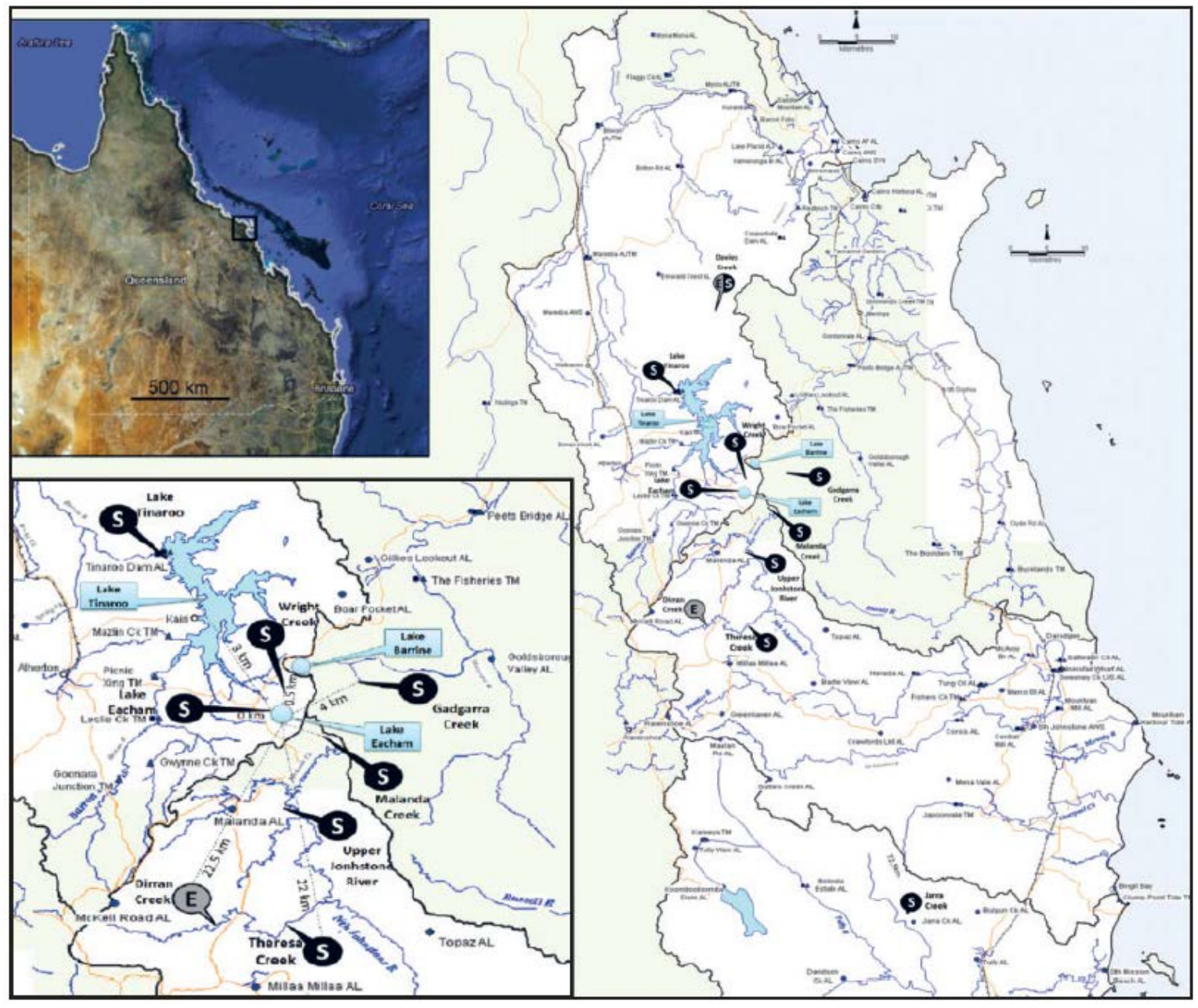


The fish were captured at each location either by seine net or in a standard bait trap (Queensland Fisheries permit \#100562). A minimum of 10 fish were photographed, fin clipped and released. The fin clips were held in $75 \%$ ethanol in individually labelled eppendorf tubes for DNA extraction.

Fig. 3. A molecular phylogenetic tree based on the sequence of the mitochondrial D-loop. M. eachamensis populations are represented by Dirran Creek and the captive eachamensis stock. The remaining populations are all M. splendida. The fish currently in Lake Eacham (LE) clearly cluster within the M. splendida populations near the bottom of the tree. Numbers next to the location abbreviations refer to specimen numbers. Refer to Table 1 for the key to collection location abbreviations.

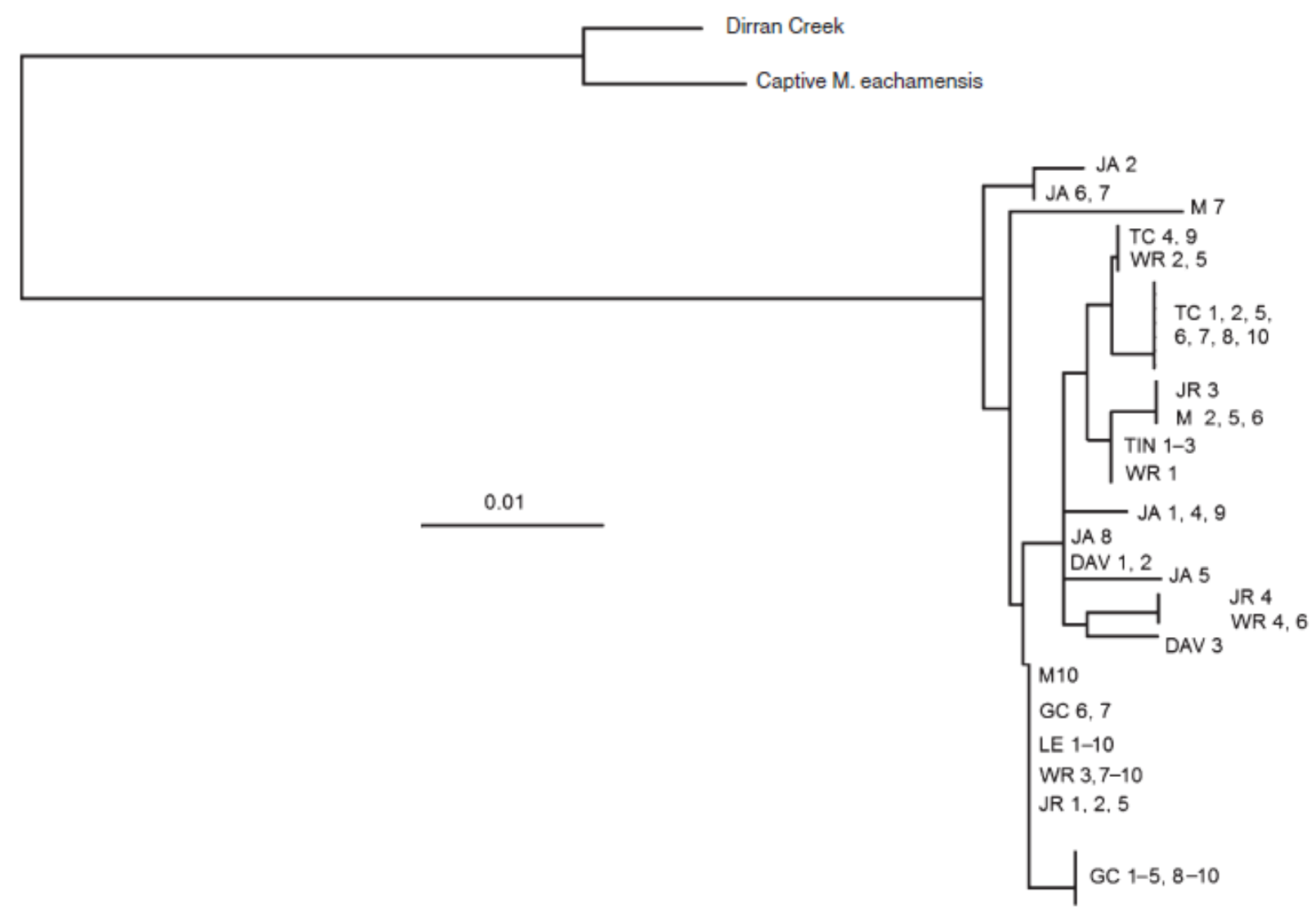

DNA was extracted from fin clips using the proteinase K/salting-out method (Sunnucks and Hales 1996), with a 3-h proteinase $\mathrm{K}$ digestion at $55^{\circ} \mathrm{C}$. The D-loop (control region) of mitochondrial DNA was amplified in a PCR using $0.2 \mu \mathrm{M}$ final concentration of universal primers CRAf and CREr (CCTCTA ACTCCCAAAGCTAG and CCTGAAGTAGGAACCAGATG respectively: Lee et al. 1995). PCRs were performed in 50-mL volumes using GoTaq white (Promega) in the buffer supplied with the enzyme, with the addition of RNAse $A$ to a final concentration of $10 \mathrm{mg} \mathrm{mL}^{-1}$. The temperature cycles for the PCR were: $94^{\circ} \mathrm{C}$ for $3 \mathrm{~min} ; 94^{\circ} \mathrm{C}$ for $30 \mathrm{~s}, 55^{\circ} \mathrm{C}$ for $30 \mathrm{~s}, 72^{\circ} \mathrm{C}$ for $1 \mathrm{~min}, 35$ cycles; $72^{\circ} \mathrm{C}$ for $5 \mathrm{~min}$. The success of amplification was assessed by electrophoresis on $2 \%$ agarose gels. PCR products were purified using ExoSap-IT (USB) digestion according to the manufacturer's instructions. Purified PCR products were sequenced using BigDye ver. 3.1 chemistry (Applied Biosystems) with the reverse primer (CREr).

Sequences were determined on an ABI 3130xI Genetic Analyzer. Sequencing reactions, unincorporated dye-terminator removal and capillary electrophoresis were carried out at the Macquarie University DNA Analysis Facility. Sequence size was 384 base pairs in length. The DNA sequences were manually edited 
and were entered into the Biomanager database (http://biomanager.info). Sequences were aligned using the ClustalW algorithm (Thompson et al. 1994). Phylogenetic relationships were assessed with a maximum-likelihood phylogram using the Tamura-Nei model of evolution and phylogenetic trees generated using MEGA ver. 5 (Tamura et al. 2011). All sequences were submitted to GenBank (accession nos: KC201362-426).

Fig. 4. Haplotype network for the fish sampled. The size of the circles refers to the number of sequences that belong to that haplotype and the small black dots refer to missing haplotypes. Haplotypes are shaded relative to the distance of the collection location from Lake Eacham. Samples taken from Lake Eacham are shaded in light grey. Note that only two samples of $M$. eachamensis are shown to illustrate the great differentiation between the two species.

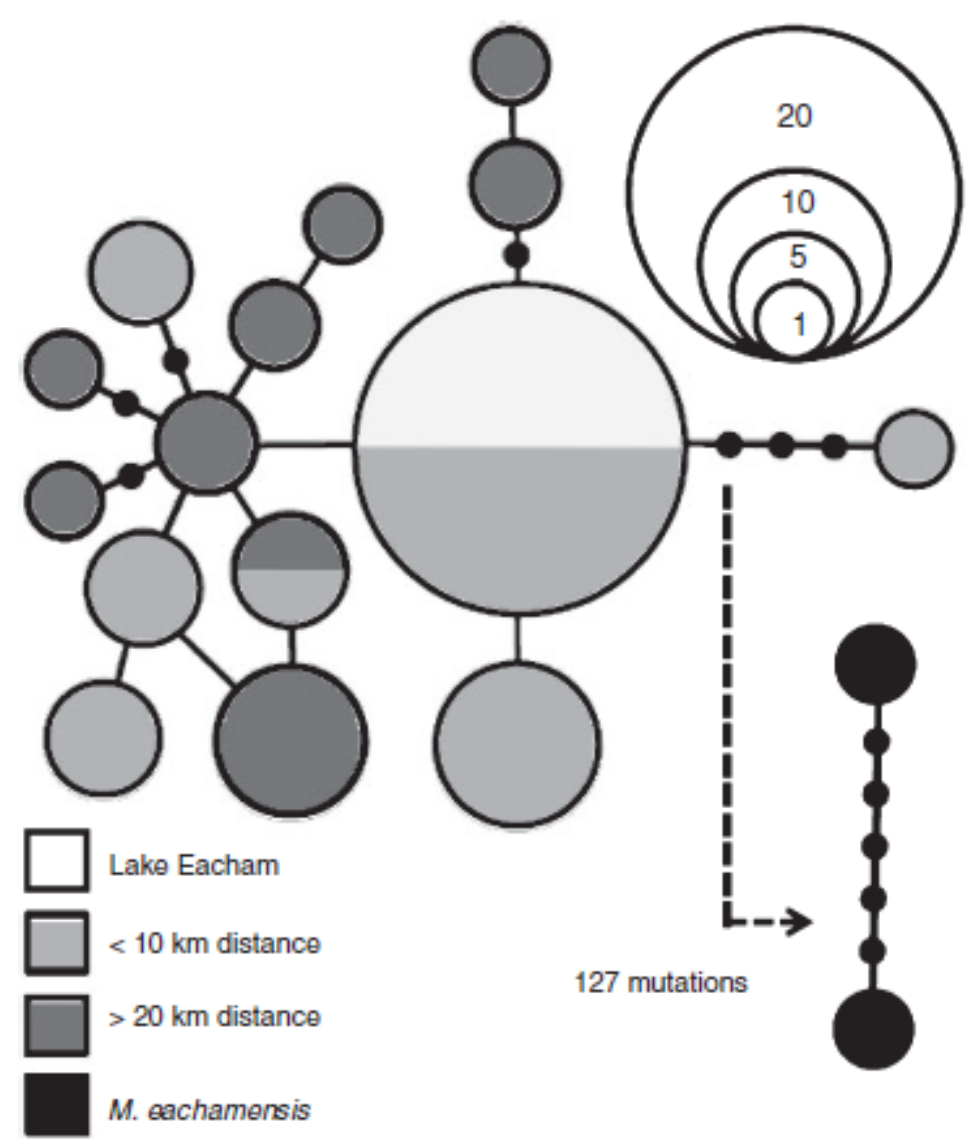

\section{Results}

Our genetic data show that the current rainbowfish occupying Lake Eacham is clearly M. splendida as it clusters with several other populations belonging to this lineage (Fig. 3). Examination of the most closely related populations of $M$. splendida in the phylogenetic tree revealed that they all occurred close to Lake Eacham. Wright Creek is $0.5 \mathrm{~km}$ to the north while Malanda Creek is $2.5 \mathrm{~km}$ to the south. The latter flows into the North Johnstone River, where another two close matches were found in the main stream. Interestingly, a few fish from Gadgarra Creek also clustered with this group. Davies Creek fish all cluster with the rest of the $M$. splendida clade. 
As further validation of these results, we noted that the wild population of $M$. eachamensis in Dirran Creek was closely related to the captive population originally collected from Lake Eacham during the early 1980s.

The haplotype network for M. splendida clearly illustrates a star cluster pattern typical of invasion and recent expansion (Fig. 4). Fifteen haplotypes were revealed from 63 sequences and a large number of fish sampled from close by shared the same haplotype as the fish presently in Lake Eacham.

\section{Discussion}

Our results clearly demonstrate that the colonisation of Lake Eacham by novelfish species is on-going despite the fact that it is a World Heritage National Park. The latest arrival in the lake has been positively identified as $M$. splendida and is most likely derived from source populations in the immediate vicinity. Wright Creek, the closest match, with several individuals sharing the same haplotype, is just 500m north of Lake Eacham. It is difficult to ascertain with any degree of certainty how these novel fish species colonised the lake but it does highlight the continuing problem of translocation in the region (Pusey et al. 2004).

Lintermans (2004) identified 12 possible means by which freshwater fish are dispersed by human activities in Australia, of which only two are relevant to the present context: discarding of aquarium fish and deliberate illegal stocking. Most researchers assumed that the previous simultaneous introduction of four species into the lake in the late 1980s pointed to a deliberate unauthorised translocation or a release from an aquarium (Barlow et al. 1987; Brown and Warburton 1997). None of the introduced species are especially targeted by anglers, so it unlikely that the release event was related to angling. A deliberate release is also possible for $M$. splendida, but this species is not commonly maintained in the aquarium hobby. Unlike the other species, however, $M$. splendida is capable of colonising new locations across land barriers without human assistance. Rainbowfish produce eggs with sticky, web-like strands that enable them to adhere to aquatic vegetation in fast-flowing water (Allen and Cross 1982). These strands could be caught on the feet or feathers of aquatic birds, or transported aloft with aquatic weeds via the same vector (Unmack 2001). Similarly, they could be accidently transferred by human bathers or on aquatic leisure craft such as kayaks. The latter is particularly likely given that Lake Eacham is a popular tourist destination. While the eggs may not be able to stay out of water for long, it would take only a few minutes for a bird to move from the suspected source streams to Lake Eacham. It is highly likely that the eggs would still be viable after such a brief trip. Further research needs to examine the viability of eggs following exposure to air.

The molecular methods utilised here allowed us to unequivocally identify the current species of rainbowfish in Lake Eacham as $M$. splendida. Confirmation that the molecular methodology is sound is shown by the close alignment between the captive population of $M$. eachamensis, which has now been in captivity for over 30 years, and the well known wild population in Dirran Creek. These results are also validated by those of earlier studies using a combination of molecular markers, including the control region sequence and multivariate morphometrics (Zhu et al. 1998; McGuigan et al. 2000).

It is interesting to note that the Lake Barine system has also been invaded by $M$. splendida, as indicated by its presence in Gadgarra Creek. Lake Barine, like Lake Eacham, is an isolated crater-lake system with only a single stream (Toohey Creek) running out of it during extremely wet seasons. Whilewe have not sampled fish in the lake itself, our sequence analysis showed that the fish in the Gadgarra Creek, a small tributary of Toohey Creek, are all relatively closely clustered together, suggesting that they may be genetically isolated from the surrounding populations. Nevertheless, they are clearly closely related to the fish currently in Lake Eacham and likely share a recent common ancestor despite the fact that they are in 
the headwaters of the Mulgrave River system. We also note that the unusual morphotype in Davies Creek is another variant of $M$. splendida.

To conclude, the freshwater ichthyofauna of the Atherton Tablelands region is highly dynamic and this is facilitated by human activities such as translocation, angling and stocking practices. The new occurrences of a range of Australian native fishes presents a significant threat to several unique, threatened rainbowfish species in the region, including $M$. eachamensis and $M$. utcheensis. Further surveys of the area coupled with molecular analyses are required to characterise diversity and identify populations for specific conservation management action.

\section{Acknowledgements}

Thanks to Derek Gerkin (Australia and New Guinea Fishes Association NSW) for supplying the captive $M$. eachamensis specimen. Thanks also to Liette Waldron for her assistance with sequencing. CB was supported by an Australian Research Fellowship from the Australian Research Council

\section{References}

Allen, G. R. (1989). Lake Eacham rainbowfish rediscovered? Fishes of Sahul 5, 217-219.

Allen, G. R., and Cross, N. J. (1982). 'Rainbowfishes of Australia and Papua New Guinea.' (Angus and Robertson: Sydney.)

Barlow, C. G., Hogan, A. E., and Rogers, L. J. (1987). Implication of translocated fishes in the apparent extinction in the wild of the Lake Eacham rainbowfish, Melanotaenia eachamensis. Australian Journal of Marine and Freshwater Research 38, 897-902. doi:10.1071/MF9870897

Brown, C. (2003). Habitat-predator association and avoidance in rainbowfish (Melanotaenia spp.). Ecology Freshwater Fish 12, 118-126. doi:10.1034/j.1600-0633.2003.00007.x

Brown, C., and Day, R. (2002). The future of stock enhancements: bridging the gap between hatchery practice and conservation biology. Fish and Fisheries 3, 79-94. doi:10.1046/j.14672979.2002.00077.x

Brown, C., and Laland, K. N. (2001). Social learning and life skills training for hatchery reared fish. Journal of Fish Biology 59, 471-493. doi:10.1111/j.1095-8649.2001.tb02354.x

Brown, C., and Warburton, K. (1997). Predator recognition and anti-predator responses in the rainbowfish Melanotaenia eachamensis. Behavioral Ecology and Sociobiology 41, 61-68. doi:10.1007/s002650050364

Brown, C., and Warburton, K. (1999). Differences in timidity and escape responses between predatornaïve and predator-sympatric rainbowfish populations. Ethology 105, 491-502. doi:10.1046/j.1439-0310.1999.00442.x

Crowley, E. L. M., and Ivantsoff, W. (1991). Genetic similarity among populations of rainbowfishes (Pices: Melanotaeniidae) from Atherton Tableland, northern Queensland. Ichthyological Exploration of Freshwaters 2, 129-137.

Faulks, L., Gilligan, D., and Beheregaray, L. (2010). Evolution and maintenance of divergent lineages in an endangered freshwater fish, Macquaria australasica. Conservation Genetics 11, 921-934. doi:10.1007/s10592-009-9936-7

Kydd, E., and Brown, C. (2009). Loss of shoaling preference for familiar individuals in captive-reared crimson spotted rainbowfish Melanotaenia duboulayi. Journal of Fish Biology 74, 2187-2195. doi:10.1111/j.1095-8649.2009.02240.x

Lee, W.-J., Conroy, J., Howell, W. H., and Kocher, T. D. (1995). Structure and evolution of teleost mitochondrial control regions. Journal of Molecular Evolution 41, 54-66. doi:10.1007/BF00174041 
Lintermans, M. (2004). Human-assisted dispersal of alien freshwater fish in Australia. New Zealand Journal of Marine and Freshwater Research 38, 481-501. doi:10.1080/00288330.2004.9517255

McGuigan, K., Zhu, D., Allen, G. R., and Moritz, C. (2000). Phylogenetic relationships and historical biogeography of melanotaeniid fishes in Australia and New Guinea. Marine and Freshwater Research 51, 713-723. doi:10.1071/MF99159

McGuigan, K., Franklin, C. E., Moritz, C., and Blows, M. W. (2003). Adaptation of rainbow fish to lake and stream habitats. Evolution 57, 104-118.

Page, T. J., Sharma, S., and Hughes, J. M. (2004). Deep phylogenetic structure has conservation implications for ornate rainbowfish (Melanotaeniidae: Rhadinocentrus ornatus) in Queensland, eastern Australia. Marine and Freshwater Research 55, 165-172. doi:10.1071/MF03139

Pusey, B. J., Bird, J., Kennard, M. J., and Arthington, A. H. (1997). Distribution of the Lake Eacham rainbowfish in the Wet Tropics region, north Queensland. Australian Journal of Zoology 45, 7584. doi:10.1071/ZO96009

Pusey, B. J., Kennard, M. J., and Arthington, A. H. (2004). 'Freshwater Fishes of North-eastern Australia.' (CSIRO Publishing: Melbourne.)

Sunnucks, P., and Hales, D. F. (1996). Numerous transposed sequences of mitochondrial cytochrome oxidase I-II in aphids of the genus Sitobion (Hemiptera: Aphididae). Molecular Biology and Evolution 13, 510-524. doi:10.1093/oxfordjournals.molbev.a025612

Tamura, K., Peterson, D., Peterson, N., Stecher, G., Nei, M., and Kumar, S. (2011). MEGA5: Molecular Evolutionary Genetics Analysis using maximum likelihood, evolutionary distance, and maximum parsimony methods. Molecular Biology and Evolution 28, 2731-2739. doi:10.1093/molbev/msr121

Thompson, J. D., and Higgins, D. G. Gibson, T. J. (1994). Clustal W: improving the sensitivity of progressive multiple sequence alignment through sequence weighting, position-specific gap penalties and weight matrix choice. Nucleic Acids Research 22, 4673-4680. doi:10.1093/nar/22.22.4673

Timms, B. V. (1979). The benthos of some lakes in northeastern Queensland. Proceedings of the Royal Society of Queensland 90, 57-64.

Unmack, P. J. (2001). Biogeography of Australian freshwater fishes. Journal of Biogeography 28, 10531089. doi:10.1046/j.1365-2699.2001.00615.x

Wager, R. (1993). The distribution and conservation status of Queensland freshwater fishes. Queensland Department of Primary Industries, Brisbane.

Zhu, D. Q., Jamieson, B. G. M., Hugall, A., and Moritz, C. (1994). Sequence evolution and phylogenetic signal in control-region and cytochrome-b sequences of rainbow fishes (Melanotaeniidae). Molecular Biology and Evolution 11, 672-683.

Zhu, D. Q., Degnan, S., and Moritz, C. (1998). Evolutionary distinctiveness and status of the endangered Lake Eacham rainbowfish (Melanotaenia eachamensis). Conservation Biology 12, 80-93. doi:10.1046/j.1523-1739.1998.96330.x

Zuberi, A., Ali, S., and Brown, C. (2011). A non-invasive assay for monitoring stress responses: A comparison between wild and captive-reared rainbowfish (Melanoteania duboulayi). Aquaculture 321, 267-272. doi:10.1016/j.aquaculture.2011.09.006 